\title{
EFFECT OF CARBONATE ON THE SOLUBILITY OF NEPTUNIUM IN NATURAL GRANITIC GROUNDWATER
}

\author{
B. Y. KIM ${ }^{1}$, J. Y. OH ${ }^{1}$, M. H. BAIK ${ }^{2}$ and J.-I. YUN ${ }^{1 *}$ \\ ${ }^{1}$ Department of Nuclear \& Quantum Engineering, KAIST \\ 373-1 Guseong-dong, Yuseong-gu, Daejeon, 305-701, Korea \\ ${ }^{2}$ Radioactive Waste Technology Development Division, Korea Atomic Energy Research Institute \\ P.O. Box 105, Yuseong-gu, Daejeon 305-353, Korea \\ ${ }^{*}$ Corresponding author. E-mail : jiyun@kaist.ac.kr
}

Received February 23, 2010

Accepted for Publication July 24, 2010

This study investigates the solubility of neptunium (Np) in the deep natural groundwater of the Korea Atomic Energy Research Institute Underground Research Tunnel (KURT). According to a Pourbaix diagram ( $\mathrm{pH}-\mathrm{E}_{\mathrm{h}}$ diagram) that was calculated using the geochemical modeling program PHREEQC 2.0, the redox potential and the carbonate ion concentration both control the solubility of neptunium. The carbonate effect becomes pronounced when the total carbonate concentration is higher than $1.5 \times 10^{-2} \mathrm{M}$ at $\mathrm{E}_{\mathrm{h}}=-200 \mathrm{mV}$ and the $\mathrm{pH}$ value is 10 . Given the assumption that the solubility-limiting stable solid phase is $\mathrm{Np}(\mathrm{OH})_{4}(\mathrm{am})$ under the reducing condition relevant to KURT, the soluble neptunium concentrations were in the range of $1 \times 10^{-9} \mathrm{M}$ to $3 \times 10^{-9} \mathrm{M}$ under natural groundwater conditions. However, the solubility of neptunium, which was calculated with the formation constants of neptunium complexes selected in an OECD-NEA TDB review, strongly deviates from the value measured in natural groundwater. Thus, it is highly recommended that a prediction of neptunium solubility is based on the formation constants of ternary $\mathrm{Np}(\mathrm{IV})$ hydroxo-carbonato complexes, even though the presence of those complexes is deficient in terms of the characterization of neptunium species. Based on a comparison of the measurements and calculations of geochemical modeling, the formation constants for the "upper limit" of the Np(IV) hydroxo-carbonato complexes, namely $\mathrm{Np}(\mathrm{OH})_{y}\left(\mathrm{CO}_{3}\right)_{z}{ }^{4-y-2 z}$, were appraised as follows: $\log \mathrm{K}^{\mathrm{o}}{ }_{122}=-3.0 \pm 0.5$ for $\mathrm{Np}(\mathrm{OH})_{2}\left(\mathrm{CO}_{3}\right)_{2}{ }^{2-}, \log \mathrm{K}^{\mathrm{o}}{ }_{131}=$ $-5.0 \pm 0.5$ for $\mathrm{Np}(\mathrm{OH})_{3}\left(\mathrm{CO}_{3}\right)^{\text {, }}$, and $\log \mathrm{K}^{\mathrm{o}}{ }_{141}=-6.0 \pm 0.5$ for $\mathrm{Np}(\mathrm{OH})_{4}\left(\mathrm{CO}_{3}\right)^{2-}$.

KEYWORDS : Neptunium, Solubility, Hydroxo-Carbonato Complexes, Granitic Groundwater, Geochemical Modeling

\section{INTRODUCTION}

Deep geological disposal is a favored method for the permanent storage of high-level radioactive waste (HLW) in a repository. Thus, fundamental knowledge of the geochemical behavior of actinides is of prime importance for ensuring the long-term safety of nuclear waste disposal when groundwater enters the repository and there is a subsequent release of radioactive waste. In general, a relatively small amount of neptunium $(\mathrm{Np})$ is contained in HLW, including spent nuclear fuels. However, the amount of neptunium can build up over a prolonged discharge time through the $\alpha$-decay of ${ }^{241} \mathrm{Am}\left(\mathrm{T}_{1 / 2}=432.7 \mathrm{yrs}\right)$ [1]. Due to its long half-life $\left({ }^{237} \mathrm{~Np}\right.$ : $\left.\mathrm{T}_{1 / 2}=2.14 \times 10^{-6} \mathrm{yrs}\right)$ and a high radiotoxicity, neptunium is an important actinide in the safety assessment of nuclear waste disposal [2].

Neptunium is likely to undergo a redox reaction and may be subject to a change in oxidation states, even under normal conditions. Owing to the different stabilities of the oxidation states, there is a noticeable difference in the chemical properties, such as solubility, complexation, sorption, and colloid formation. For oxidizing conditions, neptunium generally remains stable in a pentavalent oxidation state. In carbonate free solutions, $\mathrm{NpO}_{2} \mathrm{OH}(\mathrm{s})$ and $\mathrm{Np}_{2} \mathrm{O}_{5}(\mathrm{~s})$ are considered stable solid phases $[1,3-6]$, whereas $\mathrm{MNpO}_{2} \mathrm{CO}_{3} \cdot \mathrm{xH}_{2} \mathrm{O}$ or $\mathrm{M}_{3} \mathrm{NpO}_{2}\left(\mathrm{CO}_{3}\right)_{2}\left(\mathrm{M}=\mathrm{Na}^{+}\right.$, $\mathrm{K}^{+}$) or both are the solubility-limiting solid phases based on the X-ray powder diffraction in an equilibrium state containing carbonate. Therefore, one of the characteristics of the solubility-limiting solid phases of $\mathrm{Np}(\mathrm{V})$ is their strong reliance on the alkali carbonate concentration [1,7-12]. Additionally, many calculation studies have reported that the solubility of $\mathrm{Np}(\mathrm{IV})$ is $5 \times 10^{-9} \mathrm{M}$ in a neutral to highly alkaline solution [13] and $3 \times 10^{-9} \mathrm{M}$ for a $\mathrm{pH}$ range of 8.5-12.5 [14]. Yui reported that the solubility of $\mathrm{NpO}_{2}$ (am) was $2 \times 10^{-9} \mathrm{M}$ for reducing groundwater at a relatively high $\mathrm{pH}$ [15]. Rees determined that the $\mathrm{Np}$ solubility was $4 \times 10^{-9} \mathrm{M}$ for a $\mathrm{pH}$ of 8 and an $\mathrm{E}_{\mathrm{h}}$ value of $-0.28 \mathrm{~V}$ in deeper burial conditions [16]. The chemical form of a freshly precipitated or aged $\mathrm{Np}$ (IV) solid phase 
is not clear. In the literature, $\mathrm{NpO}_{2}$ (am) is considered a solubility-limiting phase. In neutral to alkaline solutions that are free of carbonate ions, the solubility of $\mathrm{NpO}_{2}$ (cr) becomes consistent with that of amorphous $\mathrm{Np}$ (IV) hydrous solids $[17,18]$.

As discussed in detail in a review of the OECD-NEA Thermochemical Database (TDB) [18], the presence of ternary $\mathrm{Np}(\mathrm{IV})$ hydroxo-carbonato complexes is still a controversial issue. Due to inadequate characterization of the neptunium species and the uncertainty of the solubility product of the solid phase used in the solubility experiments, the formation constants are not nominated in the OECDNEA TDB. Nevertheless, the experimental data in the literature strongly indicates that ternary $\mathrm{Np}(\mathrm{VI})$ hydroxocarbonato complexes, particularly $\mathrm{Np}(\mathrm{OH})_{2}\left(\mathrm{CO}_{3}\right)_{2}{ }^{2-}$ $[19,20], \mathrm{Np}(\mathrm{OH})_{3}\left(\mathrm{CO}_{3}\right)^{-}[21], \mathrm{Np}(\mathrm{OH})_{4}\left(\mathrm{CO}_{3}\right)^{2-}[19,21]$, and $\mathrm{Np}(\mathrm{OH})_{4}\left(\mathrm{CO}_{3}\right)_{2}{ }^{4-}[22]$, can be formed. However, data on the equilibrium constant of only one complex of either $\mathrm{Np}(\mathrm{OH})_{2}\left(\mathrm{CO}_{3}\right)_{2}{ }^{2-}$ or $\mathrm{Np}(\mathrm{OH})_{3}\left(\mathrm{CO}_{3}\right)^{-}$and either of $\mathrm{Np}(\mathrm{OH})_{4}\left(\mathrm{CO}_{3}\right)^{2-}$ or $\mathrm{Np}(\mathrm{OH})_{4}\left(\mathrm{CO}_{3}\right)_{2}{ }^{4-}$ have been reported due to a difficulty in the chemical speciation of individual ternary complexes formed in almost the same $\mathrm{pH}$ range.

In this paper, the solubility of neptunium is investigated in the natural groundwater conditions of the Korea Atomic Energy Research Institute Underground Research Tunnel (KURT). A calculation with the geochemical modeling program PHREEQC 2.0 was performed on the basis of the thermodynamic data of the OECD-NEA TDB. Even though the formation constants of ternary $\mathrm{Np}$ (IV) hydroxocarbonato complexes, which were not discussed in the OECD-NEA TDB due to a lack of data on the species characterization, are of low reliability, they consistently help explain the experimentally measured solubility of $\mathrm{Np}(\mathrm{IV})$. Thus, this paper presents a discussion and evaluation of the formation constants of the ternary $\mathrm{Np}$ (IV) hydroxocarbonato complexes relevant to the conditions of the KURT groundwater and in conjunction with the thermodynamic data reported in the literature.

\section{GEOCHEMICAL CALCULATION}

\subsection{KURT Groundwater}

KURT is located at the research site of the Korea Atomic Energy Research Institute in Yueseong, Daejeon, Republic of Korea. It was constructed to obtain detailed information on deep geologic environments and to demonstrate the performance of the Korean Reference System for HLW disposal under a repository-relevant condition in Korea. KURT is a small-scale underground research laboratory with one access tunnel (180 $\mathrm{m}$ in length) and two research modules $(45 \mathrm{~m}$ and $30 \mathrm{~m}$ in length for the right and left modules) at a depth of $100 \mathrm{~m}$ from the surface [23,24]. The rock type is two-mica granite; it is classified as calcalkali rock [25]. Fifteen boreholes were drilled at the KURT site (BH-1 to BH-6, YS-1, YS-2, YS2-1, YS2-2, and YS-3 to YS-7) to investigate the hydraulic and geological characteristics of one Korean crystalline rock formation that is considered to have potential as an HLW repository in Korea. The calculations in this study are based on natural granitic groundwater sampled from the borehole YS-1 at three different depths: $169.5 \mathrm{~m}, 259.5 \mathrm{~m}$, and $457.5 \mathrm{~m}$ [25]. The major compositions of the groundwater are presented in Table 1 . The noteworthy disparity of the three groundwater samples lies mainly in the redox potential. The YS-1-3

Table 1. Compositions of Natural Granitic Groundwaters Sampled from a KURT Borehole

\begin{tabular}{c|c|c|c}
\hline & $Y S-1-3$ & $Y S-1-4$ & $Y S-1-6$ \\
\hline Depth $(\mathrm{m})$ & 169.5 & 259.5 & 457.5 \\
Temp. $\left({ }^{\circ} \mathrm{C}\right)$ & 17.6 & 19.8 & 24.5 \\
$\mathrm{pH}$ & 10.71 & 10.23 & 9.93 \\
$\mathrm{E}_{\mathrm{h}}(\mathrm{mV})$ & 63 & -109 & -142 \\
$\mathrm{Alk} .(\times 1000)$ & 0.73 & 0.96 & 0.75 \\
\hline $\mathrm{Na}^{+}$ & 25.0 & 35.8 & 36.9 \\
$\mathrm{~K}^{+}$ & 1.14 & 0.60 & 0.58 \\
$\mathrm{Ca}^{2+}$ & 5.7 & 6.2 & 2.4 \\
$\mathrm{SiO}_{2}$ & 27.4 & 25 & 18.2 \\
$\mathrm{HCO}_{3}{ }^{-} \mathrm{CO}_{3}^{2-}$ & 11.6 & 6.4 & 1.9 \\
$\mathrm{~F}^{-}$ & 8.1 & 13.9 & 9.0 \\
$\mathrm{NO}_{3}^{-}$ & 3.7 & 17.1 & 20.1 \\
$\mathrm{SO}_{4}{ }^{-2}$ & 2.0 & 11.5 & 12.1 \\
$\mathrm{Cl}^{-}$ & 3.0 & 2.2 & 3.8 \\
\hline
\end{tabular}

conc. unit $=[\mathrm{mg} / \mathrm{L}]$

Table 2. The Groundwater Composition of YS-1-7 [26]

\begin{tabular}{c|c|c|c}
\hline Element & Conc. $(\mathrm{mg} / \mathrm{L})$ & Element & Conc. $(\mathrm{mg} / \mathrm{L})$ \\
\hline $\mathrm{Na}^{+}$ & 17.4 & $\mathrm{CO}_{3}{ }^{2-}+\mathrm{HCO}_{3}{ }^{-}$ & 78.4 \\
$\mathrm{Ca}^{2+}$ & 17.3 & $\mathrm{Cl}^{-}$ & 2.18 \\
$\mathrm{Mg}^{2+}$ & 1.82 & $\mathrm{SO}_{4}{ }^{2-}$ & 6.97 \\
$\mathrm{~K}^{+}$ & 0.26 & $\mathrm{~F}^{-}$ & 3.41 \\
$\mathrm{Li}^{+}$ & $1.7 \times 10^{-2}$ & $\mathrm{SiO}_{2}$ & 41.3 \\
$\mathrm{Sr}^{+}$ & 0.27 & $\mathrm{~W}$ & $1.9 \times 10^{-2}$ \\
$\mathrm{Mn}$ & $2.2 \times 10^{-2}$ & $\mathrm{Fe}$ & $5.0 \times 10^{-2}$ \\
$\mathrm{Al}$ & $1.6 \times 10^{-2}$ & $\mathrm{Ba}^{2+}$ & $9.0 \times 10^{-2}$ \\
$\mathrm{Mo}$ & $3.8 \times 10^{-2}$ & $\mathrm{pH}$ & 8.44 \\
\hline
\end{tabular}


groundwater sample comprises an oxidizing condition, whereas the YS-1-4 and YS-1-6 groundwater samples reveal a reducing condition. The $\mathrm{pH}$ value of the groundwater ranges between 9.9 and 10.7. The temperature is increased from the surface of the earth with a geothermal gradient of $+2.6{ }^{\circ} \mathrm{C} / 100 \mathrm{~m}$ of depth at the KURT site.

For a comparison of the neptunium solubility with that from various experimental results, the calculation of solubility and the neptunium species was performed with the YS-1-7 groundwater [26]. The geochemical properties of YS-1-7 are analogous to other experimental conditions in the literature $[19,21,22,26,27]$. The $E_{h}$ value of the YS1-7 groundwater, with a higher carbonate concentration of $78.4 \mathrm{mg} / \mathrm{L}$ at a depth of $140 \mathrm{~m}$ to $150 \mathrm{~m}$, is $-200 \mathrm{mV}$. The compositions are listed in Table 2.

\subsection{Calculation of Solubility and Chemical Species}

The calculation of the solubility and chemical species of neptunium was performed with the geochemical modeling program PHREEQC 2.0 and data from the OECD-NEA TDB [18]. The chemical reactions and formation constants of the neptunium species are summarized in Table 3 . The solubility product of $\mathrm{NpO}_{2}$ (am,hyd) at zero ionic strength, $\log \mathrm{K}_{\mathrm{sp}}^{0}$, which is selected in the OECD-NEA TDB, was used as follows [18]:

$$
\begin{gathered}
\mathrm{NpO}_{2}(\mathrm{am}, \mathrm{hyd})+2 \mathrm{H}_{2} \mathrm{O}(1) \leftrightarrow \mathrm{Np}^{4+}+4 \mathrm{OH}^{-} \\
\log \mathrm{K}_{\mathrm{sp}}{ }^{\mathrm{o}}=-56.7 \pm 0.5 .
\end{gathered}
$$

Hydrolysis and carbonate complexation may also occur in parallel to form ternary hydroxo-carbonato complexes. However, the experimental solubility data for $\mathrm{NpO}_{2}$ (am,hyd) in the presence of carbonate ions are inconsistent. Moreover, a large degree of uncertainty may exist between different methods of conducting the solubility experiments (under-saturation or over-saturation) and due to the probable particle size effect of the solid phases on solubility, which has not yet been clearly elucidated [18]. Owing to the large degree of uncertainty about the solubility data and the lack of data on the species characterization [18], the equilibrium constants for ternary $\mathrm{Np}$ (IV) hydroxo-carbonato complexes are not nominated in the OECD-NEA TDB, even though there is a strong indication of the formation

\begin{tabular}{|c|c|}
\hline Reaction & $\log \mathrm{K}^{\mathrm{o}}$ \\
\hline $\mathrm{Np}^{4+}+\mathrm{H}_{2} \mathrm{O}(\mathrm{l}) \leftrightarrow \mathrm{NpOH}^{3+}+\mathrm{H}^{+}$ & $0.55 \pm 0.2$ \\
\hline $\mathrm{Np}^{4+}+2 \mathrm{H}_{2} \mathrm{O}(\mathrm{l}) \leftrightarrow \mathrm{Np}(\mathrm{OH})_{2}{ }^{2+}+2 \mathrm{H}^{+}$ & $0.35 \pm 0.3$ \\
\hline $\mathrm{Np}^{4+}+4 \mathrm{H}_{2} \mathrm{O}(\mathrm{l}) \leftrightarrow \mathrm{Np}(\mathrm{OH})_{4}(\mathrm{aq})+4 \mathrm{H}^{+}$ & $-8.3 \pm 1.1$ \\
\hline $\mathrm{Np}^{4+}+2 \mathrm{H}_{2} \mathrm{O}=\mathrm{NpO}_{2}^{+}+4 \mathrm{H}^{+}+\mathrm{e}^{-}$ & -10.212 \\
\hline $\mathrm{NpO}_{2}^{+}+\mathrm{H}_{2} \mathrm{O}(\mathrm{l}) \leftrightarrow \mathrm{NpO}_{2} \mathrm{OH}(\mathrm{aq})+\mathrm{H}^{+}$ & $-11.3 \pm 0.7$ \\
\hline $\mathrm{NpO}_{2}^{+}+2 \mathrm{H}_{2} \mathrm{O}(\mathrm{l}) \leftrightarrow \mathrm{NpO}_{2}(\mathrm{OH})_{2}^{-}+2 \mathrm{H}^{+}$ & $-23.6 \pm 0.5$ \\
\hline $\mathrm{NpO}_{2}^{2+}+\mathrm{H}_{2} \mathrm{O}(\mathrm{l}) \leftrightarrow \mathrm{NpO}_{2} \mathrm{OH}^{+}+\mathrm{H}^{+}$ & $-5.1 \pm 0.4$ \\
\hline $2 \mathrm{NpO}_{2}^{2+}+2 \mathrm{H}_{2} \mathrm{O}(\mathrm{l}) \leftrightarrow\left(\mathrm{NpO}_{2}\right)_{2}(\mathrm{OH})_{2}{ }^{2+}+2 \mathrm{H}^{+}$ & $-6.27 \pm 0.21$ \\
\hline $3 \mathrm{NpO}_{2}^{2+}+5 \mathrm{H}_{2} \mathrm{O}(\mathrm{l}) \leftrightarrow\left(\mathrm{NpO}_{2}\right)_{3}(\mathrm{OH})_{5}^{+}+5 \mathrm{H}^{+}$ & $-17.12 \pm 0.22$ \\
\hline $\mathrm{NpO}_{2}^{2+}+\mathrm{CO}_{3}^{2-} \leftrightarrow \mathrm{NpO}_{2} \mathrm{CO}_{3}(\mathrm{aq})$ & $9.32 \pm 0.61$ \\
\hline $\mathrm{NpO}_{2}^{+}+\mathrm{CO}_{3}^{2-} \leftrightarrow \mathrm{NpO}_{2}\left(\mathrm{CO}_{3}\right)^{-}$ & $4.962 \pm 0.061$ \\
\hline $\mathrm{NpO}_{2}^{2+}+2 \mathrm{CO}_{3}^{2-} \leftrightarrow \mathrm{NpO}_{2}\left(\mathrm{CO}_{3}\right)_{2}^{2-}$ & $16.516 \pm 0.729$ \\
\hline $\mathrm{NpO}_{2}\left(\mathrm{CO}_{3}\right)^{-}+\mathrm{CO}_{3}{ }^{2-} \leftrightarrow \mathrm{NpO}_{2}\left(\mathrm{CO}_{3}\right)_{2}^{3-}$ & $1.572 \pm 0.083$ \\
\hline $\mathrm{Np}\left(\mathrm{CO}_{3}\right)_{5}^{6-}+\mathrm{e}^{-} \leftrightarrow \mathrm{Np}\left(\mathrm{CO}_{3}\right)_{3}^{3-}+2 \mathrm{CO}_{3}^{2-}$ & $-16.261 \pm 2.265$ \\
\hline $\mathrm{NpO}_{2}\left(\mathrm{CO}_{3}\right)_{3}{ }^{5-} \leftrightarrow \mathrm{NpO}_{2}\left(\mathrm{CO}_{3}\right)_{3}{ }^{4-}+\mathrm{e}^{-}$ & $-5.72 \pm 0.095$ \\
\hline $\mathrm{NpO}_{2}\left(\mathrm{CO}_{3}\right)_{2-}^{3-}+\mathrm{CO}_{3}{ }^{2-} \leftrightarrow \mathrm{NpO}_{2}\left(\mathrm{CO}_{3}\right)_{3}{ }^{5-}$ & $-1.034 \pm 0.11$ \\
\hline $\mathrm{NpO}_{2}($ am,hyd $)+4 \mathrm{CO}_{3}{ }^{2-}+2 \mathrm{H}_{2} \mathrm{O}(\mathrm{l}) \leftrightarrow \mathrm{Np}\left(\mathrm{CO}_{3}\right)_{4}{ }^{4}+4 \mathrm{OH}^{-}$ & $-17.79 \pm 0.22$ \\
\hline $\mathrm{Np}\left(\mathrm{CO}_{3}\right)_{4}^{4}+\mathrm{CO}_{3}{ }^{2-} \leftrightarrow \mathrm{Np}\left(\mathrm{CO}_{3}\right)_{5}^{6-}$ & $-1.07 \pm 0.3$ \\
\hline $3 \mathrm{NpO}_{2}\left(\mathrm{CO}_{3}\right)_{3}{ }^{4-} \leftrightarrow\left(\mathrm{NpO}_{2}\right)_{3}\left(\mathrm{CO}_{3}\right)_{6}{ }^{6-}+3 \mathrm{CO}_{3}{ }^{2-}$ & $-8.272 \pm 1.447$ \\
\hline
\end{tabular}

Table 3 The Reactions and the Formation Constants of Neptunium Hydroxide and Carbonate Complexes [18] 
of mixed $\mathrm{Np}(\mathrm{IV})$ hydroxo-carbonato species in alkaline carbonate-containing solutions [19,20].

\section{RESULTS AND DISCUSSION}

\subsection{Solubility and Chemical Speciation of Neptunium in the Granitic Groundwater of KURT}

Anionic groundwater constituents are ubiquitous in natural groundwater. Tables 1 and 2 list the minor anionic ligands present in natural groundwater, including $\mathrm{F}^{-}, \mathrm{Cl}^{-}$, $\mathrm{SO}_{4}{ }^{2-}$, and $\mathrm{NO}_{3}{ }^{-}$. However, only the fluoride ions marginally affect neptunium speciation when the $\mathrm{pH}$ is less than 4.5 , particularly where $\mathrm{NpF}_{2}{ }^{2+}$ is the predominant $\mathrm{Np}(\mathrm{IV})$ fluoride complex $(74 \%)$ at a $\mathrm{pH}$ of 4.0 . Under reducing conditions and at higher $\mathrm{pH}, \mathrm{NpF}_{2}{ }^{2+}$ is suppressed by the strong hydrolysis reactions of $\mathrm{Np}$ (IV).

Fig. 1 shows the calculated solubility of $\mathrm{Np}(\mathrm{IV})$ in the YS-1 groundwater. The tetravalent neptunium complexes control the solubility of neptunium in the granitic groundwater condition of KURT. With data from the OECD-NEA TDB, the solubility of neptunium was calculated to be $2.75 \times 10^{-9}$ $\mathrm{M}$ in the YS-1-3 $\left(\mathrm{pH}=10.71, \mathrm{E}_{\mathrm{h}}=63 \mathrm{mV}\right)$ and $1.0 \times 10^{-9}$ $\mathrm{M}$ in the YS-1-4 $\left(\mathrm{pH}=10.23, \mathrm{E}_{\mathrm{h}}=-109 \mathrm{mV}\right)$ and the YS-1$6\left(\mathrm{pH}=9.93, \mathrm{E}_{\mathrm{h}}=-142 \mathrm{mV}\right)$. These values are very consistent with other calculated solubilities reported in the literature [13-16]. Beyond a $\mathrm{pH}$ level of 12, the solubilitylimiting solid phase was transformed from $\mathrm{NpO}_{2}$ (am,hyd) into $\mathrm{Np}_{2} \mathrm{O}_{5}$ (cr) in the YS-1-3 groundwater. This transformation may be ascribed to the slightly oxidizing condition of the YS-1-3 groundwater, which allows the pentavalent neptunium species to become dominant. In a carbonatecontaining solution, the solid $\mathrm{Np}$ (IV) hydroxo-carbonato complex, $\mathrm{Np}(\mathrm{OH})_{2}\left(\mathrm{CO}_{3}\right)(\mathrm{s})$, is considered the most

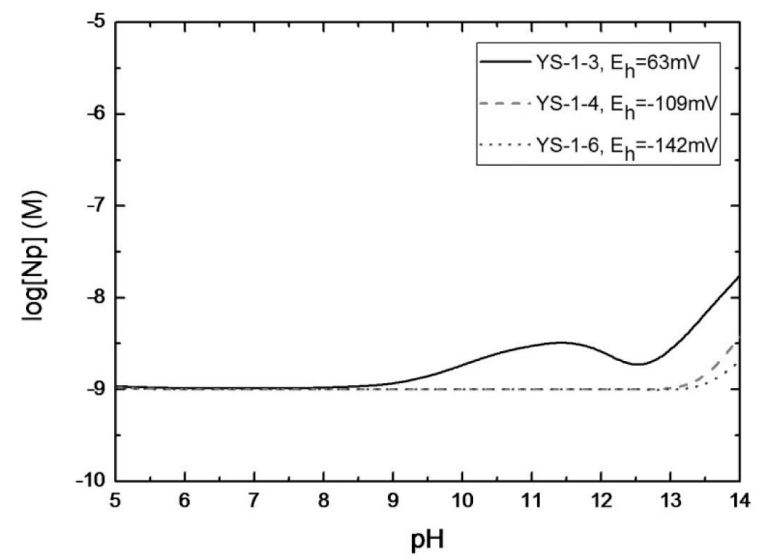

Fig. 1. Solubility Curves of Neptunium in the YS-1 Groundwater; the Calculations are Derived by Using PHREEQC 2.0 Based on the OECD-NEA TDB thermodynamically stable solid phase. However, a concentration ratio of $10^{-9.4}$ between $\mathrm{Np}(\mathrm{OH})_{2}\left(\mathrm{CO}_{3}\right)(\mathrm{s})$ and $\mathrm{Np}(\mathrm{OH})_{4}(\mathrm{am})$ was derived in a carbonate concentration range of $5 \times 10^{-4} \mathrm{M}$ to $5 \times 10^{-3} \mathrm{M}$ [22]. Therefore, $\mathrm{Np}(\mathrm{OH})_{4}$ (am) is highly abundant and can consequently be considered a solubility-limiting phase for a carbonate concentration range of $3.1 \times 10^{-5} \mathrm{M}$ to $1.3 \times 10^{-3} \mathrm{M}$ in the YS-1 groundwater condition. As yet, however, there is no reliable thermodynamic and crystallographic data available for solid $\mathrm{Np}(\mathrm{IV})$ carbonate or hydroxo-carbonato ternary complexes [1].

Fig. 2 shows the chemical species distribution of neptunium in the YS-1 groundwater. The predominant species under the reducing condition is $\mathrm{Np}(\mathrm{OH})_{4}(\mathrm{aq})$. At a $\mathrm{pH}$ level higher than that of the groundwater from the YS-1-3 sample, $\mathrm{NpO}_{2} \mathrm{CO}_{3}^{-}$and $\mathrm{NpO}_{2}(\mathrm{OH})_{2}{ }^{-}$appear and help raise the solution's $\mathrm{pH}$ level. A Pourbaix diagram, which is shown pictorially in Fig. 3, was calculated for different groundwater conditions so that the change in solubility could be predicted for the various groundwater conditions. Initially the influence of the groundwater compositions on the distribution of the $\mathrm{Np}$ (IV) chemical
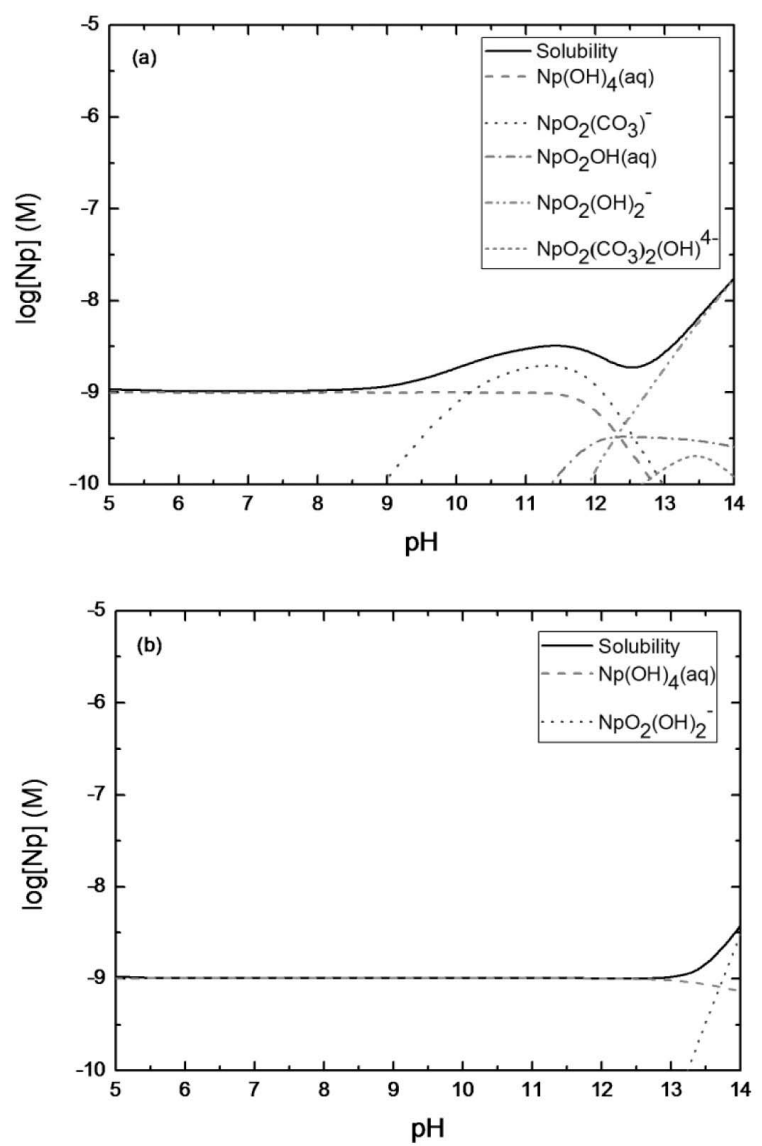

Fig. 2. Calculation of Soluble Neptunium Concentrations in the YS-1 Groundwater: (a) YS-1-3 and (b) YS-1-4 
species can be neglected. Remarkably, the dominant species and its overriding $\mathrm{pH}-\mathrm{E}_{\mathrm{h}}$ range are unchanged in the various groundwater compositions. However, the formation of the neptunium carbonate complexes varies slightly among the YS-1 groundwater samples, depending on the solution's $\mathrm{pH}$ and the total carbonate concentration.
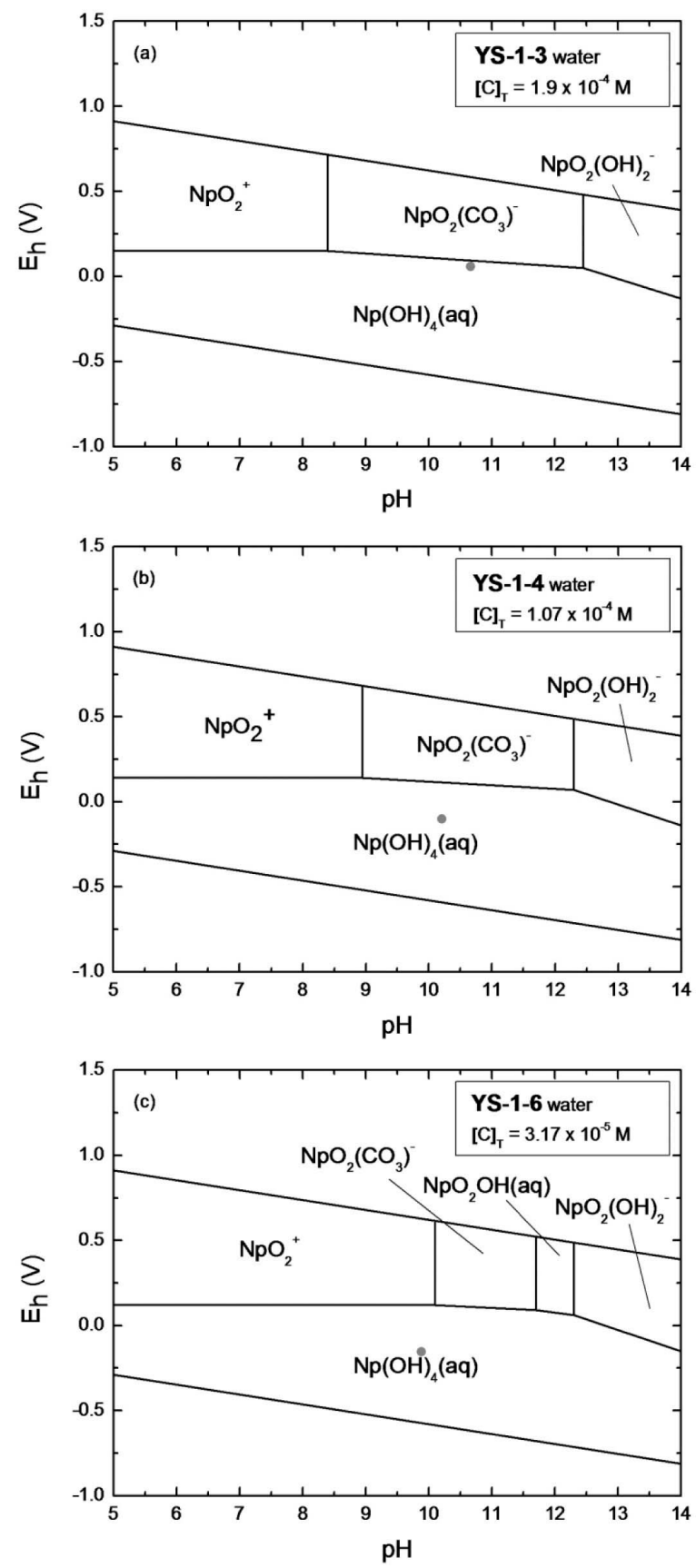

Fig. 3. Pourbaix $\left(E_{h}-p H\right)$ Diagrams for Each Sample of the KURT Groundwater: (a) YS-1-3, (b) YS-1-4, and (c) YS-1-6 (closed circle)
The solubility curve was calculated as a function of the total carbonate concentration at a $\mathrm{pH}$ value of 9.93 to corroborate the carbonate effect on solubility. The total carbonate concentration influences the major species distribution of neptunium. As shown in Fig. 4, the solubility data differ from the total carbonate concentration and the redox potential of the groundwater. The notable influence of the carbonate effect on the solubility curve of neptunium shifts to a slightly higher carbonate concentration as the redox potential value decreases. The carbonate effect becomes pronounced when the total carbonate concentration is greater than $2.5 \times 10^{-3} \mathrm{M}$ at $\mathrm{E}_{\mathrm{h}}=-100 \mathrm{mV}$ and greater than $1.5 \times 10^{-2} \mathrm{M}$ at $\mathrm{E}_{\mathrm{h}}=-200 \mathrm{mV}$. The total soluble neptunium concentration has an increasing tendency due to the carbonate complex formation of $\mathrm{Np}(\mathrm{V})$, particularly $\mathrm{NpO}_{2}\left(\mathrm{CO}_{3}\right)_{2}{ }^{3-}$ and $\mathrm{NpO}_{2} \mathrm{CO}_{3}{ }^{-}$. However, the dominant soluble species is still $\mathrm{Np}(\mathrm{OH})_{4}(\mathrm{aq})$ when the total carbonate concentration remains lower than that of the $\mathrm{Np}(\mathrm{V})$ carbonate complexation.

\subsection{Comparison of Solubilities by Measurements and Calculation}

In the YS-1 groundwater, the total carbonate concentration is much lower the experimental value reported in the literature $[19,21,22,26,27]$. For the purpose of comparison between calculated and experimental solubility, the YS-1-7 groundwater, which has the highest carbonate concentration of all the groundwater samples, was used for the solubility calculation. The experimental solubility study was performed with YS-1-7 groundwater at a total carbonate concentration of about $1.3 \times 10^{-3} \mathrm{M}$ and a redox potential $\left(\mathrm{E}_{\mathrm{h}}\right)$ of $-200 \mathrm{~m}$ [26]. Thus, a direct comparison was made between measured and calculated solubility by applying the YS-1-7 groundwater. The total carbonate concentration is defined and calculated

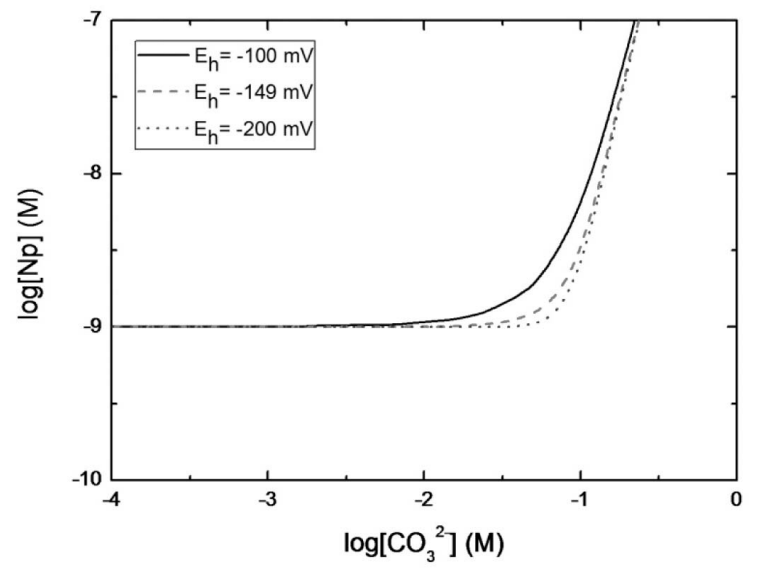

Fig. 4. Solubility Curves for $\mathrm{Np}(\mathrm{OH})_{4}(\mathrm{am})$ as a Function of the Total Carbonate Concentration at a pH Level of 9.93 and Different $E_{h}$ Values 
as follows [18]:

$$
\begin{gathered}
{[\mathrm{C}]_{\mathrm{T}}=\left[\mathrm{HCO}_{3}{ }^{-}\right]+\left[\mathrm{CO}_{3}{ }^{2-}\right]} \\
\mathrm{HCO}_{3}{ }^{-}=\mathrm{CO}_{3}{ }^{2-}+\mathrm{H}^{+} \quad \log \mathrm{K}^{\circ}=-10.329 .
\end{gathered}
$$

Generally, it is difficult to perform a solubility experiment in the only tetravalent oxidation state of neptunium, particularly under conditions of a possible oxidizing geologic environment $[20,22,28]$. Accordingly, a reducing agent or potentiometer is used to control the $\mathrm{E}_{\mathrm{h}}$ value throughout the experiments for the purpose of maintaining the redox environment. In the literature [20], there is a careful analysis of the effectiveness of $\mathrm{NH}_{2} \mathrm{OH} \cdot \mathrm{HCl}, \mathrm{NH}_{2} \mathrm{NH}_{2}$, and $\mathrm{Na}_{2} \mathrm{~S}_{2} \mathrm{O}_{4}$ as reducing reagents, and the results reveal that $\mathrm{Na}_{2} \mathrm{~S}_{2} \mathrm{O}_{4}$ is a highly effective reagent.

Various solubility experiments were carried out through under-saturation [20-22]. However, Kitamura and Kohara performed $\mathrm{Np}(\mathrm{IV})$ solubility experiments through both under-saturation and over-saturation methods in $2 \mathrm{M} \mathrm{NaClO}_{4}$ solution with a total carbonate concentration of $0.1 \mathrm{M}$ and in the $\mathrm{pH}$ range of 9 to 13 [19]. Due to the high ionic strength of the solution, the experimental data shown in Fig. 5 were corrected to zero ionic strength according to the SIT (specific ion interaction theory). Eriksen and colleagues obtained solubility data from carbonate-containing solutions with a total carbonate concentration of $\mathrm{C}_{\mathrm{T}}=10^{-3}-10^{-1} \mathrm{M}$ in the $\mathrm{pH}$ range of 8.1 to 12.2 [21]. Pratopo et al. determined the solubility by evaporating an aliquot of filtrate in the carbonate concentration range of $\mathrm{C}_{\mathrm{T}}=5 \times 10^{-4} \mathrm{M}$ to $5 \times 10^{-3}$ $\mathrm{M}$ at $\mathrm{pH}$ of 8 to 12.5 [22]. Kim et al. performed the experiment with $\mathrm{NpO}_{2}$ powder put into the groundwater; the activity of ${ }^{237} \mathrm{~Np}$ in a filtered sample solution was measured at $\mathrm{pH}$ 9.5, 10.2, and 11.1 at a controlled $\mathrm{E}_{\mathrm{h}}=-0.2 \mathrm{~V}$ [26]. The calculation of solubility was made under the same groundwater conditions as those of YS-1-7 performed by Kim et al., based on the formation constants selected in OECD-NEA TDB. However, as can be seen in Fig. 5, the solubility values reported by Kim et al. [26] are higher than those calculated based on the OECD-NEA TDB. Moreover, the wide range of scatters of the $\mathrm{Np}(\mathrm{IV})$ solubility data has been attributed particularly to the different carbonate concentrations (Fig. 5). This finding was confirmed by correction of the carbonate concentration (see Fig. 6(a)).

The formation constants of $\mathrm{Np}(\mathrm{IV})$ ternary complexes have not been selected in the OECD-NEA TDB because of the reasons stated earlier. Nevertheless, for a reasonable account of the experimentally measured solubility data from the literature, the formation of $\mathrm{Np}(\mathrm{IV})$ hydroxocarbonato complexes needs to be considered. In contrast, spectroscopic investigations have been undertaken to ascertain the nature of $\mathrm{Np}(\mathrm{V})$ hydroxo-carbonato complexes, particularly $\mathrm{NpO}_{2}(\mathrm{OH})_{y}\left(\mathrm{CO}_{3}\right)_{z}{ }^{1-y-2 z}[1,9,29]$. In the case of $\mathrm{Np}(\mathrm{V})$ solubility, the calculated $\mathrm{Np}(\mathrm{V})$ solubility agrees well with the measured solubility [1]. In this study, we considered the equilibrium constants of $\mathrm{Np}(\mathrm{OH})_{y}\left(\mathrm{CO}_{3}\right)_{z}{ }^{4-y-2 z}$ as reported in various studies for the PHREEQC 2.0 calculation of the soluble neptunium concentration. Table 5 lists the formation constants reported in the literature for $\mathrm{Np}$ (IV) hydroxo-carbonato complexes.

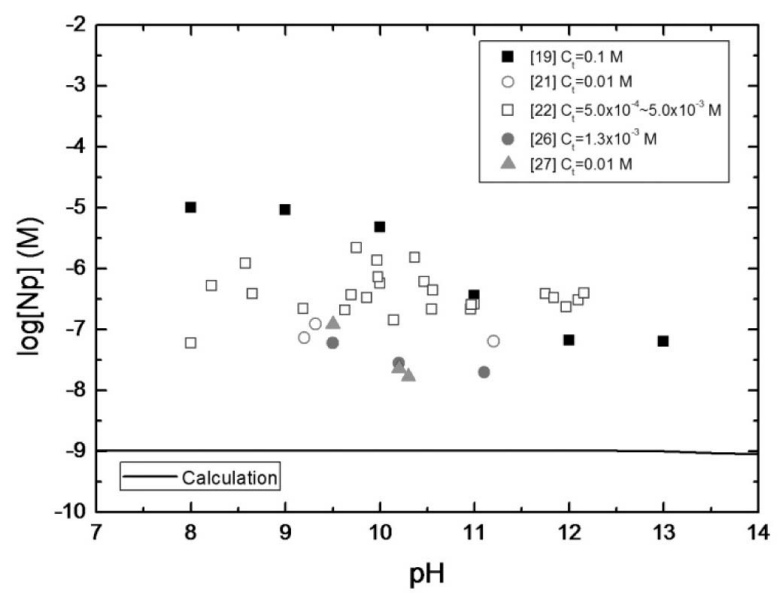

Fig. 5. Comparison of Solubility by Measurements with Calculation. Calculation was Performed Based on the Formation Constants Selected in OECD-NEA TDB

Table 4. The Reactions and the Formation Constants of $\mathrm{NpO}_{2} \cdot \mathrm{xH}_{2} \mathrm{O}(\mathrm{am})$ and Carbonate/Bicarbonate Complexes

\begin{tabular}{c|c|c|c|c}
\hline \multirow{2}{*}{ Reaction } & \multicolumn{4}{|c}{$\log \mathrm{K}^{\circ}$} \\
\cline { 2 - 5 } & {$[19]$} & {$[20]$} & {$[21]$} & $-54.5 \pm 0.3$ \\
\hline $\mathrm{NpO}_{2} \cdot \mathrm{xH}_{2} \mathrm{O}(\mathrm{am}) \leftrightarrow \mathrm{Np}^{4+}+4 \mathrm{OH}^{-}+(\mathrm{x}-2) \mathrm{H}_{2} \mathrm{O}$ & $-56.7 \pm 0.5$ & $-54.5 \pm 0.3$ & $-54.5 \pm 0.3$ & -6.381 \\
\hline $\mathrm{H}_{2} \mathrm{CO}_{3} \leftrightarrow \mathrm{H}^{+}+\mathrm{HCO}_{3}^{-}$ & -6.35 & - & -10.377 & - \\
\hline $\mathrm{HCO}_{3} \leftrightarrow \leftrightarrow \mathrm{H}^{+}+\mathrm{CO}_{3}^{2-}$ & -10.33 & - & -9.77 \\
\hline
\end{tabular}


The calculation of the formation constants of neptunium was based on the equilibrium constants of $\mathrm{NpO}_{2} \cdot \mathrm{XH}_{2} \mathrm{O}(\mathrm{am})$ in an aqueous carbonate system. Pratopo et al. determined the formation constants of $\mathrm{Np}(\mathrm{OH})_{2}\left(\mathrm{CO}_{3}\right)_{2}{ }^{2-}$ and $\mathrm{Np}(\mathrm{OH})_{4}\left(\mathrm{CO}_{3}\right)_{2}{ }^{4-}[22]$. From a perspective analogous to that of the $\mathrm{Pu}(\mathrm{IV})$ experiment, they considered $\mathrm{Np}(\mathrm{OH})_{4}\left(\mathrm{CO}_{3}\right)_{2}{ }^{4-}$ as the dominant species at $\mathrm{pH}$ levels higher than 10. Using experimental data, Kitamura et al. [19] used nonlinear leastsquares fitting for their numerical computations. For $\mathrm{pH}$ levels higher than $11, \mathrm{~Np}(\mathrm{OH})_{4}\left(\mathrm{CO}_{3}\right)_{2}{ }^{4-}$ and $\mathrm{Np}(\mathrm{OH})_{4}\left(\mathrm{CO}_{3}\right)^{2-}$ were both considered for the calculation of the formation constants. Due to the high degree of uncertainty in the calculated formation constants, the contribution of $\mathrm{Np}(\mathrm{OH})_{4}\left(\mathrm{CO}_{3}\right)_{2}{ }^{4-}$ was neglected. However, Eriksen et al. considered only hydroxo-monocarbonato species [21]. Furthermore, in the experiment of Rai et al. [20], $\mathrm{Np}(\mathrm{OH})_{2}\left(\mathrm{CO}_{3}\right)_{2}{ }^{2-}$ was assumed, analogously to uranium, to be an aqueous hydroxo-carbonato species at a low bicarbonate concentration. Table 4 presents the equilibrium constants used to calculate the formation constants of the $\mathrm{Np}$ (IV) hydroxo-carbonato complexes in the literature.

The total soluble neptunium concentration was calculated by using the formation constants of the $\mathrm{Np}$ (IV) hydroxocarbonato complexes listed in Table 5. However, when compared to the experimentally determined solubility data, the calculated solubility values of $\mathrm{Np}$ (IV) are largely underestimated and were not predicted even with the ternary $\mathrm{Np}$ (IV) formation constants reported in the literature. Therefore, the large degree of uncertainty surrounding the formation constants of $\mathrm{Np}(\mathrm{OH})_{2}\left(\mathrm{CO}_{3}\right)_{2}{ }^{2-}, \mathrm{Np}(\mathrm{OH})_{3} \mathrm{CO}_{3}{ }^{-}$, $\mathrm{Np}(\mathrm{OH})_{4} \mathrm{CO}_{3}{ }^{2-}$, and $\mathrm{Np}(\mathrm{OH})_{4}\left(\mathrm{CO}_{3}\right)_{2}{ }^{4-}$ must be appraised cautiously. In this study, "upper limits" of the formation constants of $\mathrm{Np}$ (IV) ternary complexes were calculated. The suggested dominant species are $\mathrm{Np}(\mathrm{OH})_{2}\left(\mathrm{CO}_{3}\right)_{2}{ }^{2-}$ or $\mathrm{Np}(\mathrm{OH})_{3}\left(\mathrm{CO}_{3}\right)^{-}$or both at a $\mathrm{pH}$ value of less than 10 , and $\mathrm{Np}(\mathrm{OH})_{4}\left(\mathrm{CO}_{3}\right)^{2-}$ or $\mathrm{Np}(\mathrm{OH})_{4}\left(\mathrm{CO}_{3}\right)_{2}{ }^{4-}$ or both at a $\mathrm{pH}$ value greater than 10 . This suggests that the dominant species are closely influenced by the fact that bicarbonate ions, $\mathrm{HCO}_{3}{ }^{-}$, are predominant for a $\mathrm{pH}$ value of less than 10 whereas carbonate ions, $\mathrm{CO}_{3}{ }^{2-}$, are more significant for a $\mathrm{pH}$ value greater than 10 . The scattered neptunium solubility data from various experiments were obtained at different total carbonate concentrations and corrected to $0.01 \mathrm{M}$ total carbonate concentration. The solubility experiment of Pratopo et al. was performed at varied carbonate concentrations [22]: Kim et al. provided only the experimentally measured solubility [26]. Therefore, these two studies were not considered for the calculation of the formation constants of the Np(IV) ternary complexes in this study. The Boltzmann non-linear curve has been used to fit the solubility data from the various studies as the "upper limit" (Fig. 6(a)).

For the calculation of solubility when the $\mathrm{pH}$ is less than 10 , either $\mathrm{Np}(\mathrm{OH})_{2}\left(\mathrm{CO}_{3}\right)_{2}{ }^{2-}$ or $\mathrm{Np}(\mathrm{OH})_{3}\left(\mathrm{CO}_{3}\right)^{-}$was selected. The task of experimentally differentiating the complexes $\mathrm{Np}(\mathrm{OH})_{2}\left(\mathrm{CO}_{3}\right)_{2}{ }^{2-}$ and $\mathrm{Np}(\mathrm{OH})_{3}\left(\mathrm{CO}_{3}\right)^{-}$is difficult. Therefore, for a $\mathrm{pH}$ value of less than 10, one hydroxocarbonato species was selected for the calculation. In this study, the formation constant of $\mathrm{Np}(\mathrm{OH})_{4}\left(\mathrm{CO}_{3}\right)_{2}{ }^{4-}$ was not included in the calculation because of its negligibly small contribution to the $\mathrm{Np}$ (IV) solubility and the large degree of uncertainty surrounding the formation [19]. The total concentration of the aqueous neptunium species relevant to conditions of natural groundwater was calculated by the following general expression for all possible hydroxide, carbonate, and hydroxide carbonate complexes:

$$
\begin{aligned}
& {[\mathrm{Np}(\mathrm{aq})]_{\mathrm{T}}=\left[\mathrm{Np}(\mathrm{OH})_{\mathrm{y}}\left(\mathrm{CO}_{3}\right)_{\mathrm{z}}{ }^{4-\mathrm{y}-2 \mathrm{z}}\right]} \\
& +\left[\mathrm{NpO}_{2}(\mathrm{OH})_{\mathrm{y}}\left(\mathrm{CO}_{3}\right)_{\mathrm{z}}{ }^{1-\mathrm{y}-2 \mathrm{z}}\right] .
\end{aligned}
$$

The formation constants of the Np(IV) hydroxo-carbonato species were calculated by fitting the experimental data,

\begin{tabular}{|c|c|c|c|c|c|c|}
\hline \multirow{2}{*}{ Species } & \multirow{2}{*}{ Reaction } & \multicolumn{5}{|c|}{$\log \mathrm{K}^{\mathrm{o}}$} \\
\hline & & [19] & {$[20]$} & {$[21]$} & {$[22]^{a}$} & This study \\
\hline $\mathrm{Np}(\mathrm{OH})_{3}\left(\mathrm{CO}_{3}\right)^{-}$ & $\mathrm{Np}(\mathrm{OH})_{4}(\mathrm{am})+\mathrm{HCO}_{3}^{-}=\mathrm{Np}(\mathrm{OH})_{3}\left(\mathrm{CO}_{3}\right)^{-}+\mathrm{H}_{2} \mathrm{O}$ & & & -5.0 & & $-5.0 \pm 0.5$ \\
\hline $\mathrm{Np}(\mathrm{OH})_{2}\left(\mathrm{CO}_{3}\right)_{2}^{2-}$ & $\mathrm{Np}(\mathrm{OH})_{4}(\mathrm{am})+2 \mathrm{HCO}_{3}^{-}=\mathrm{Np}(\mathrm{OH})_{2}\left(\mathrm{CO}_{3}\right)_{2}{ }^{2-}+2 \mathrm{H}_{2} \mathrm{O}$ & -3.0 & -4.44 & & -0.35 & $-3.0 \pm 0.5$ \\
\hline $\mathrm{Np}(\mathrm{OH})_{4}\left(\mathrm{CO}_{3}\right)^{2-}$ & $\mathrm{Np}(\mathrm{OH})_{4}(\mathrm{am})+\mathrm{CO}_{3}{ }^{2-}=\mathrm{Np}(\mathrm{OH})_{4}\left(\mathrm{CO}_{3}\right)^{2-}$ & -6.2 & & -5.23 & & $-6.0 \pm 0.5$ \\
\hline $\mathrm{Np}(\mathrm{OH})_{4}\left(\mathrm{CO}_{3}\right)_{2}^{4-}$ & $\mathrm{Np}(\mathrm{OH})_{4}(\mathrm{am})+2 \mathrm{CO}_{3}{ }^{2-}=\mathrm{Np}(\mathrm{OH})_{4}\left(\mathrm{CO}_{3}\right)_{2}{ }^{4-}$ & & & & -1.43 & \\
\hline
\end{tabular}

Table 5 The Reactions and the Formation Constants of the Np(IV) Hydroxo-Carbonato Complexes

${ }^{\mathrm{a}} \log \mathrm{K}$ is estimated in $0.1 \mathrm{M} \mathrm{Na}_{2} \mathrm{~S}_{2} \mathrm{O}_{4}$ solution. This value is not corrected to $\mathrm{I}=0$ due to the lack of the ion interaction coefficients, $\varepsilon\left(\mathrm{Np}(\mathrm{OH})_{2}\left(\mathrm{CO}_{3}\right)_{2}{ }^{2-}, \mathrm{Na}^{+}\right)$and $\varepsilon\left(\mathrm{Np}(\mathrm{OH})_{4}\left(\mathrm{CO}_{3}\right)_{2}{ }^{4-}, \mathrm{Na}^{+}\right)$ 

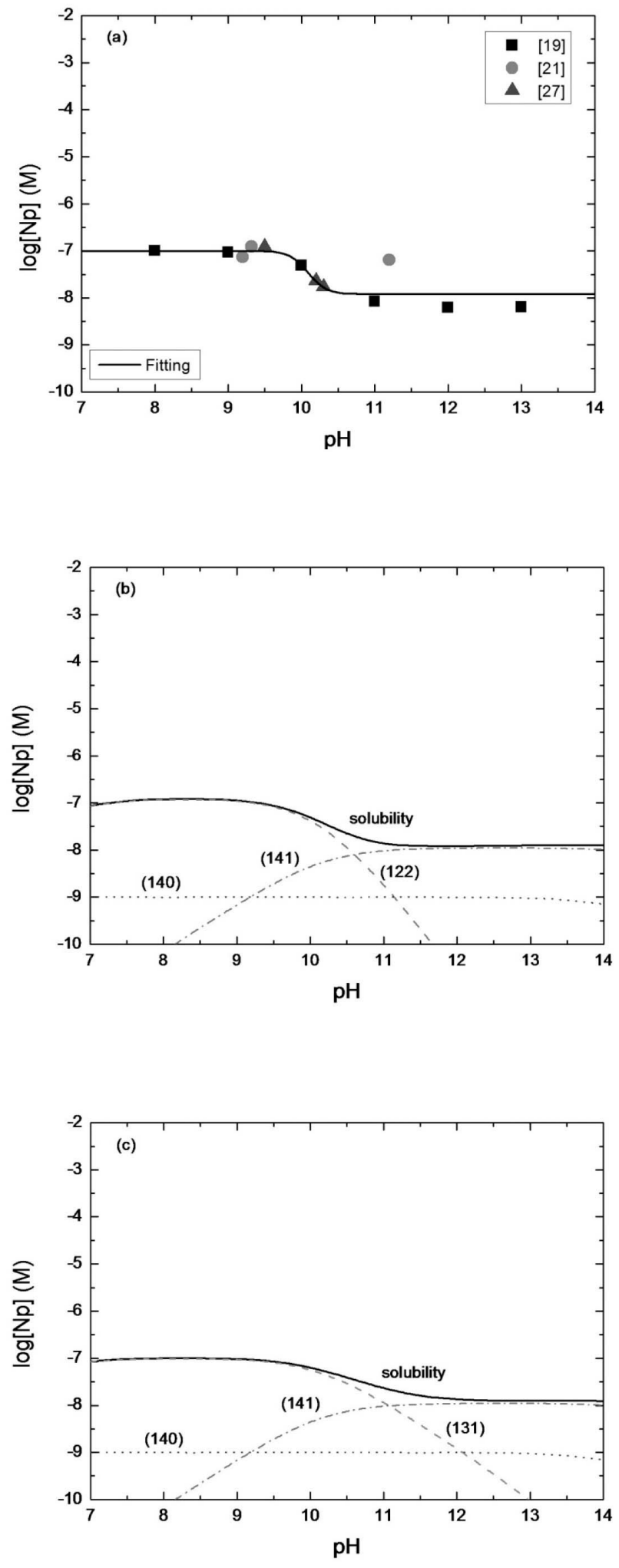

Fig. 6. Corrected Solubility Curve at $\mathrm{C}_{\mathrm{T}}=0.01 \mathrm{M}$ : (a) with Non-Linear Curve Fit as "Upper Limit", (b) and (c) with Modified Formation Constants of the Np(IV) HydroxoCarbonato Complexes as "Upper Limit" and the Distribution of the Np(IV) Ternary Complexes

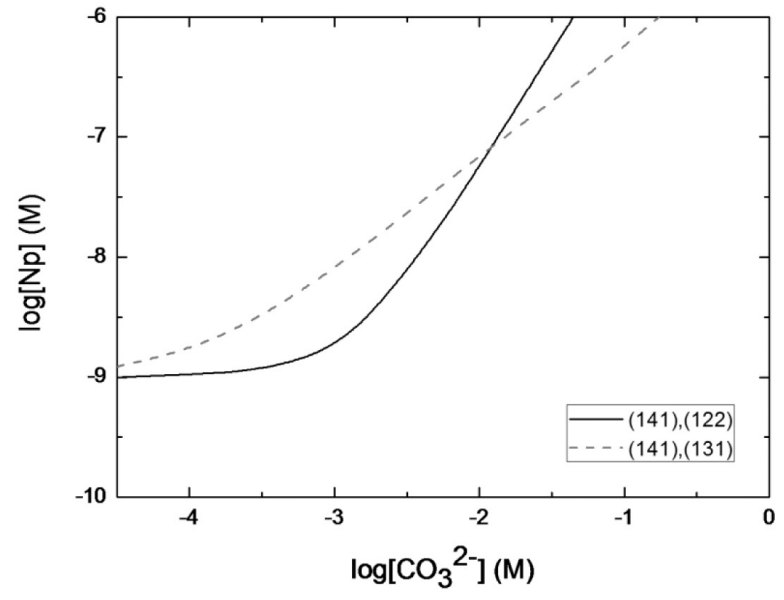

Fig. 7. Calculated Solubility Curves with the Modified Formation Constants of $\mathrm{Np}(\mathrm{OH})_{\mathrm{y}}\left(\mathrm{CO}_{3}\right)_{\mathrm{z}}{ }^{4-\mathrm{y}-2 \mathrm{z}}$ as a Function of the Total Carbonate Concentration at a $\mathrm{pH}$ Level of 9.93

as shown in Fig. 6(a). The equilibrium reactions of $\mathrm{Np}(\mathrm{OH})_{2}\left(\mathrm{CO}_{3}\right)_{2}{ }^{2-}, \mathrm{Np}(\mathrm{OH})_{3}\left(\mathrm{CO}_{3}\right)^{-}$, and $\mathrm{Np}(\mathrm{OH})_{4}\left(\mathrm{CO}_{3}\right)^{2-}$ are as follows:

$$
\begin{gathered}
\mathrm{Np}(\mathrm{OH})_{4}(\mathrm{am})+2 \mathrm{HCO}_{3}^{-}=\mathrm{Np}(\mathrm{OH})_{2}\left(\mathrm{CO}_{3}\right)_{2}{ }^{2-}+2 \mathrm{H}_{2} \mathrm{O} \\
\mathrm{Np}(\mathrm{OH})_{4}(\mathrm{am})+\mathrm{HCO}_{3}{ }^{-}=\mathrm{Np}(\mathrm{OH})_{3}\left(\mathrm{CO}_{3}\right)^{-}+\mathrm{H}_{2} \mathrm{O} \\
\mathrm{Np}(\mathrm{OH})_{4}(\mathrm{am})+\mathrm{CO}_{3}{ }^{2-}=\mathrm{Np}(\mathrm{OH})_{4}\left(\mathrm{CO}_{3}\right)^{2-}
\end{gathered}
$$

The "upper limits" of the formation constants were estimated to be $\log \mathrm{K}^{\circ}{ }_{122}=-3.0 \pm 0.5$ for $\mathrm{Np}(\mathrm{OH})_{2}\left(\mathrm{CO}_{3}\right)_{2}{ }^{2-}$, $\log \mathrm{K}^{\mathrm{o}}{ }_{131}=-5.0 \pm 0.5$ for $\mathrm{Np}(\mathrm{OH})_{3}\left(\mathrm{CO}_{3}\right)^{-}$, and $\log \mathrm{K}^{\mathrm{o}}{ }_{141}=$ $-6.0 \pm 0.5$ for $\mathrm{Np}(\mathrm{OH})_{4}\left(\mathrm{CO}_{3}\right)^{2-}$.

The solubility and the chemical species distribution are plotted in Figs. 6(b) and 6(c) with the modified equilibrium constants for the $\mathrm{Np}(\mathrm{IV})$ hydroxo-carbonato complexes at $0.01 \mathrm{M}$ total carbonate concentration. Note that at a $\mathrm{pH}$ value less than 10.5, $\mathrm{Np}(\mathrm{OH})_{2}\left(\mathrm{CO}_{3}\right)_{2}{ }^{2-}$ or $\mathrm{Np}(\mathrm{OH})_{3}\left(\mathrm{CO}_{3}\right)^{-}$ appears to be predominant, whereas $\mathrm{Np}(\mathrm{OH})_{4} \mathrm{CO}_{3}{ }^{2-}$ dominates at a $\mathrm{pH}$ value greater than 10.5 .

As illustrated in Fig. 4, the effect of the carbonate ion on the $\mathrm{Np}(\mathrm{IV})$ solubility was recalculated as a function of the total carbonate concentration at a $\mathrm{pH}$ value of 9.93 . The formation constants of the Np hydroxo-carbonato species modified in the work were taken into account for the prediction of the carbonate effect on the $\mathrm{Np}$ solubility. As shown in Fig. 7, the solubility steadily increases independently of $E_{h}$ without any notable influence of the carbonate effect on the $\mathrm{Np}(\mathrm{IV})$ solubility. However, the solubility curve shows a large disparity depending on the species selection of 
either $\mathrm{Np}(\mathrm{OH})_{2}\left(\mathrm{CO}_{3}\right)_{2}{ }^{2-}$ or $\mathrm{Np}(\mathrm{OH})_{3}\left(\mathrm{CO}_{3}\right)^{-}$. $\mathrm{Np}(\mathrm{OH})_{2}\left(\mathrm{CO}_{3}\right)_{2}{ }^{2-}$ is the dominant species at total carbonate concentration above $1.3 \times 10^{-3} \mathrm{M}$ and $\mathrm{Np}(\mathrm{OH})_{3}\left(\mathrm{CO}_{3}\right)^{-}$is the dominant at total carbonate concentration above $1.4 \times 10^{-4} \mathrm{M}$. In summary, the solubility calculated with the modified $\mathrm{K}^{\circ}{ }_{131}$ and $\mathrm{K}^{\circ}{ }_{141}$ is mainly controlled by the species concentration of $\mathrm{Np}(\mathrm{OH})_{2}\left(\mathrm{CO}_{3}\right)_{2}{ }^{2-}$ and $\mathrm{Np}(\mathrm{OH})_{3}\left(\mathrm{CO}_{3}\right)^{-}$. The control is independent of the total carbonate concentration.

\section{CONCLUSION}

This study investigated the solubility and aqueous species of $\mathrm{Np}$ in the natural granitic groundwater of KURT. The geochemical modeling program PHREEQC 2.0 was used to calculate the solubility of $\mathrm{Np}$ and to obtain a Pourbaix diagram for the different chemical conditions of groundwater sampled at different depths of the YS-1 borehole at KURT. The species distribution of $\mathrm{Np}(\mathrm{IV})$ in groundwater is not significantly affected by the groundwater composition. However, the $\mathrm{pH}$ range for the formation of the neptunium carbonate complexes differs in relation to the total carbonate concentration. The carbonate effect on the $\mathrm{Np}$ (IV) solubility is noticeable for carbonate concentrations greater than $2.5 \times 10^{-3} \mathrm{M}$ at $\mathrm{E}_{\mathrm{h}}=-100 \mathrm{mV}$ and $1.5 \times 10^{-2} \mathrm{M}$ at $\mathrm{E}_{\mathrm{h}}=-200$ $\mathrm{mV}$. The solubility calculated with data from the OECDNEA TDB is lower than the solubility values measured in various experiments. Thus, consideration of the ternary $\mathrm{Np}(\mathrm{IV})$ hydroxo-carbonate complexes is necessary for a consistent description of neptunium solubility. In the present work, the "upper limits" of the formation constants of $\mathrm{Np}(\mathrm{OH})_{x}\left(\mathrm{CO}_{3}\right)_{y}{ }^{4-x-2 y}$ were estimated by fitting measured solubility data from the literature to the calculated solubility. Nonetheless, clear experimental evidence of the formation of the $\mathrm{Np}(\mathrm{IV})$ ternary hydroxo-carbonato complexes must be found in the future.

\section{ACKNOWLEDGEMENTS}

This work was supported by the Nuclear R\&D program through the National Research Foundation of Korea funded by the Ministry of Education, Science and Technology.

This work is the outcome of a Manpower Development Program for Energy \& Resources supported by the Ministry of Knowledge and Economy (MKE).

\section{REFERENCES}

[ 1 ] J. P. Kaszuba and W. H. Runde, "The aqueous geochemistry of neptunium: Dynamic control of soluble concentrations with applications to nuclear waste disposal", Environ. Sci. Technol., 33, 4427 (1999).

[2] J. I. Kim, "Significance of actinide chemistry for the longterm safety of waste disposal", Nucl. Eng. Technol., 38, 459 (2006).

[ 3 ] C. Lierse, W. Treiber, and J. I. Kim, "Hydrolysis reactions of neptunium(V)", Radiochim. Acta., 38, 27 (1985).

[4] V. Neck, J. I. Kim, and B. Kanellakopulos, "Solubility and hydrolysis behavior of neptunium(V)", Radiochim. Acta., 56, 25 (1992).

[ 5 ] L. Merli and J. Fuger, "Thermochemistry of a Few Neptunium and Neodymium Oxides and Hydroxides", Radiochim. Acta., 66/67, 109 (1994).

[ 6 ] D.W. Efurd, W. Runde, J. C. Banar, D. R. Janecky, J. P. Kaszuba, P. D. Palmer, F. R. Roensch, and C. D. Tait, "Neptunium and plutonium solubilities in a Yucca Mountain groundwater", Environ. Sci. Technol., 32, 3893 (1998).

[7] L. Maya, "Hydrolysis and carbonate complexation of dioxoneptunium(V) in 1.0-M $\mathrm{NaClO}_{4}$ at $25^{\circ} \mathrm{C}$ ', lnorg. Chem., 22, 2093 (1983).

[ 8 ] I. Grenthe, P. Robouch, and P. Vitorge, "Chemical equilibria in actinide carbonate systems", J. Less-Common Met., 122, 225 (1986).

[9] V. Neck, W. Runde, J. I. Kim, and B. Kanellakopulos, "Solidliquid equilibrium reactions of neptunium(V) in carbonate solution at different ionic strength", Radiochim. Acta., 65, 29 (1994).

[10] V. Neck, W. Runde, and J. I. Kim, "Solid-liquid equilibria of neptunium(V) in carbonate solutions of different ionic strengths: II. Stability of the solid phases", J. Alloys Comp., 225, 295 (1995).

[11] C. F. Novak, I. Al Mahamid, K. A. Becraft, S. A. Carpenter, N. Hakem, and T. Prussin, "Measurement and Thermodynamic Modeling of $\mathrm{Np}(\mathrm{V})$ Solubility in Aqueous $\mathrm{K}_{2} \mathrm{CO}_{3}$ Solutions to High Concentrations", J. Sol. Chem., 26, 681 (1997).

[12] I. A. Mahamid, C.F. Novak, K.A Becraft, S. A. Carpenter, and N. Hakem, "Solubility of $\mathrm{Np}(\mathrm{V})$ in $\mathrm{K}-\mathrm{Cl}-\mathrm{CO}_{3}$ and Na$\mathrm{K}-\mathrm{Cl}-\mathrm{CO}_{3}$ Solutions to High Concentrations: Measurements and Thermodynamic Model Predictions", Radiochim. Acta., 81, 93 (1998).

[13] D. Rai and J. L. Ryan, "Neptunium(IV) hydrous oxide solubility under reducing and carbonate conditions", Inorg. Chem., 24, 247 (1985).

[14] R. M. Pratopo, H. Moriyama, and K. Higashi, "The behaviour of Neptunium under reducing conditions", Proceedings of 1989 Joint International Waste Management Conference, Kyoto, Japan, Oct. 22-28, 1989.

[15] M. Yui, "Database development of glass dissolution and radionuclide migration for performance analysis of HLW repository in Japan”, J. Nucl. Mater., 298, 136 (2001).

[16] J. H. Rees, "The theoretical derivation of solubilities of longlived radionuclides in disposal", J. Nucl. Mater., 130, 336 (1985).

[17] V. Neck and J. I. Kim, "Solubility and hydrolysis of tetravalent actinides", Radiochim. Acta, 89, 1 (2001).

[18] F. J. Mompean, M. Illemassene, C. D. Orti, and K. B. Said, Update on the Chemical Thermodynamics of Uranium, Neptunium, Plutonium, Americium and Technetium, Vol. 5, ELSEVIER B.V., Amsterdam (2003).

[19] A. Kitamura and Y. Kohara, "Carbonate complexation of neptunium(IV) in highly basic solutions", Radiochim. Acta, 92, 583 (2004).

[20] D. Rai, N. J. Hess, A. R. Felmy, and D. A. Moore, "A thermodynamic model for the solubility of $\mathrm{NpO}_{2}(\mathrm{am})$ in the aqueous $\mathrm{K}^{+}-\mathrm{HCO}_{3}{ }^{-}-\mathrm{CO}_{3}{ }^{2-}-\mathrm{OH}^{-}-\mathrm{H}_{2} \mathrm{O}$ system", Radiochim. Acta, 84, 159 (1999).

[21] T. E. Eriksen, P. Ndalamba, D. Cui, J. Bruno, M. Caceci, and K. Spahiu, "Solubility of the redox-sensitive radionuclides ${ }^{99} \mathrm{Tc}$ and ${ }^{237} \mathrm{~Np}$ under reducing conditions in neutral to alkaline 
solutions; effect of carbonate", SKB-TR-93-18, Swedish Nuclear Fuel and Waste Management Co. (1993).

[22] M. I. Pratopo, H. Moriyama, and K. Higashi, "Carbonate complexation of neptunium(IV) and analogous complexation of ground-water uranium", Radiochim. Acta, 51, 27 (1990).

[23] S. Kwon, C. S. Lee, S. J. Cho, S. W. Jeon, and W. J. Cho, "An investigation of the excavation damaged zone at KAERI underground research tunnel", Tunn. Undergr. Sp. Tech., 24, 1 (2009).

[24] W. -J. Cho, S. Kwon, and J. H. Park, "KURT, a small-scale underground research laboratory for the research on a highlevel waste disposal", Ann. Nucl. Energy, 35, 132-140 (2008).

[25] D. S. Bae, C. S. Kim, K. S. Kim, Y. K. Koh, J. H. Hwang, and J. R. Kim, "Assessment of deep geological environment condition”, KAERI /RR-2783/2006, Korea Atomic Energy Research Institute (2007).

[26] S. S. Kim, M. H. Baik, and K. C. Kang, "Solubility of neptunium oxide in the KURT (KAERI Underground Research Tunnel) groundwater", J. Radioanal. Nucl. Chem., 280, 577 (2009).

[27] A. Kitamura and Y. Kohara, "Solubility of Np(IV) under carbonate conditions", Report JNC TC8400 2001-006, Japan Nuclear Fuel Cycle Development Institute (2001).

[28] H. Moriyama, M. I. Pratopo, and K. Higashi, "The solubility and colloidal behavior of Neptunium(IV)", Sci. Tot. Environ., 83, 227 (1989).

[29] V. Neck, Th. Fanghänel, and J. I. Kim, "Mixed hydroxocarbonato complexes of neptunium(V)", Radiochim. Acta, 77, 167 (1997). 